\title{
Small Ruminant Breeding Plans for Smallholder Systems
}

\section{(Strategi Pembibitan Ternak untuk Sistem Peternak Kecil)}

\author{
Luis Iniguez \\ Animal Breeding Expert, Bolivia \\ luisiniguez8@gmail.com \\ (Diterima 1 Agustust 2016 - Direvisi 16 Januari 2017 - Disetujui 27 Februari 2017)
}

\begin{abstract}
The transfer of animal genetic improvement strategies in the environments of resource-poor smallholder producers in developing countries has not been successful. Therefore, the access by farmers to sources of animals with high genetic potential is difficult or just not possible. As producers improve or intensify their systems to capture market opportunities, this access need is accentuated. This paper reviews identified constraints to the transfer of breeding plans, the need for a new approach, and the lessons learned in applying a better-targeted approach. The issues and thoughts were derived from the experience of a working group involving the International Center for Agricultural Research in the Dry Areas; Austrian University of Natural Resources and Life Sciences; Argentinean National Institute of Agriculture Technology; Brazilian Agricultural Research Corporation (Embrapa Goats and Sheep); and National Research Institute for Forestry, Agriculture and Animal Production-Mexico. The transfer of breeding strategies in smallholder systems is not a straightforward task. Contrasting a successful application in commercial livestock production environments, the achievement of the primary objectives in smallholder systems requires a holistic approach beyond pure technical matters. Of all identified aspects with direct incidence in the implementation of breeding plans, the lack of specific national policies coupled with long-term funding to support the improvement of smallholder production systems, and the lack of involvement and participation of the communities emerge as issues that gravitate more to achieve sustainability and meet the objectives of a given breeding plan.
\end{abstract}

Key words: Breeding plan, policy, participatory approach, smallholder

\begin{abstract}
ABSTRAK
Strategi transfer teknologi pemuliaan untuk perbaikan genetik ternak pada peternak kecil di negara berkembang belum berhasil. Oleh karena itu, akses petani terhadap potensi genetik berkualitas tinggi masih sulit. Dalam memperbaiki dan mengintensifkan sistem untuk membuka peluang pasar, maka produsen harus memperluas akses peternak kecil terhadap ternak unggul. Makalah ini mengulas kendala yang teridentifikasi dalam transfer strategi pemuliaan, kebutuhan akan terobosan baru yang lebih tepat sasaran. Isu dan pemikiran dirangkup dari pengalaman kerjasama dengan International Center for Agricultural Research in the Dry Areas; Austrian University of Natural Resources and Life Sciences; Argentinean National Institute of Agriculture Technology; Brazilian Agricultural Research Corporation (Embrapa Goats and Sheep); and National Research Institute for Forestry, Agriculture and Animal Production-Mexico. Transfer strategi pemuliaan pada peternak kecil bukanlah tugas yang mudah. Berbeda dengan penerapan strategi pemuliaan yang berhasil di lingkungan produsen ternak komersial, pada peternak kecil memerlukan pendekatan secara holistik di luar masalah teknis. Berdasarkan semua aspek yang telah teridentifikasi dalam penerapan strategi pemuliaan, ternyata masih dibutuhkan kebijakan pemerintah yang lebih spesifik, pembiayaan jangka panjang dan partisipasi komunitas peternak yang lebih luas untuk menjamin berlangsungnya keberlanjutan penerapan strategi pemuliaan.
\end{abstract}

Kata kunci: Strategi pemuliaan, kebijakan, pendekatan partisipasif, peternak kecil

\section{INTRODUCTION}

The transfer of animal genetic improvement strategies in the environments of resource-poor smallholder producers in developing countries has not been successful, in contrast to their rapid adoption by commercial systems. Therefore, the access by farmers to sources of animals with high genetic potential is difficult or just not possible (Iñiguez et al. 2013). As producers improve or intensify their systems to capture market opportunities this access need is accentuated.

With a focus on small ruminants, this paper reviews identified constraints to the transfer of breeding plans, the need for a new approach and the lessons learned in applying a better targeted approach. The issues and thoughts discussed derive from the experience of a working group involving The International Center for Agricultural Research in the 
Dry Areas; Austrian University of Natural Resources and Life Sciences; Argentinean National Institute of Agriculture Technology (INTA-Bariloche); Brazilian Agricultural Research Corporation (Embrapa Goats and Sheep); and National Research Institute for Forestry, Agriculture and Animal Production-Mexico (ICARDA 2005; Iniguez 2011; Wurzinger et al. 2011; Iñiguez et al. 2013). A more extended version of this topic can also be found in Iñiguez et al. (2013).

\section{MAIN IDENTIFIED CONSTRAINTS THAT LIMIT THE TRANSFER OF BREEDING PLANS}

Significant identified limitations that infringe on the process of transfer breeding strategies for smallholders include (Iñiguez et al. 2013):

1. Poor police development about the use and improvement of animal genetic resources, more often lack of or inappropriate national/regional policies.

2. Poor economic development of areas where smallholder systems concentrate and their production prevails.

3. Problems inherent in the production systems: particularly in relation to the small size of herds/flocks that characterize smallholder systems; limited use of technological inputs; use of communal land for grazing that hinders the control of matings; lack of production records and individual animal identification; and dependency on markets and intermediation that do not differentiate by product condition and quality.

4. Weaknesses in the interactions between supporting/ supervising institutions and smallholder systems.

5. Information gaps, given the poor characterization of the production systems, the population base, and the production context.

6. Problems inherent to the breeding plans, excessive centralization; minimum participation of producers; lack of pertinence and improvisation without scientific basis (e.g. distribution of European breeds, regardless their relevance and adaptation to local conditions).

7. Poor funding scenarios, affecting negatively on the needed sustainability and long-term projection of breeding plans. Without a stable solid funding condition, most plans last only until the project that initiated and funded them ended, this creating producers' frustration and a negative future receptivity to similar initiatives.

\section{TRADITIONAL APPROACHES FOLLOWED IN THE GENETIC IMPROVEMENT FOR SMALLHOLDERS}

Attempts to transfer genetic improvement technologies in smallholder systems involved selection and crossbreeding. These were conducted by National Research Institutions and national/regional governments, aiming at improving animal productivity. The private sector also played a part in these processes, although not specifically aiming at the genetic improvement of the smallholder systems. Its influence was rather a byproduct of introductions of exotic breeds to improve the productivity of commercial systems. In these cases, exotic breeds were sold to smallholders interested in their appearance, with no indications of the conditions needed to raise the introduced breeds and their crossbreds.

\section{Selection}

The centralized breeding nucleus was promoted in most developing countries as the primary selection tool; however, it failed to resolve the demand by smallholders for access to improved animals. The main reasons for this were because: (1) Selection was applied within the nucleus, under controlled conditions (in the environments of research centers) and not on the environments where the animals of the base produce; and (2) The nil or, if any, limited involvement of producers, so that their interests and expectations, as well as market trends with which they interact, were not considered (Iñiguez 2005a; 2005b).

In many cases, selection achieved substantial progress within the nucleus as was handled by sound expertise, but failed to improve the base due to poor dissemination or just because the dissemination was not included in the process (Iñiguez et al. 2013).

There are however exceptions to be mentioned. These involved the Argentinean nuclei of Merino sheep and Angora goats pursuing the improvement of fiber production, induced and supported by INTA-Bariloche, and the Cyprus nuclei of Damascus goats and Chios sheep seeking milk production improvement, under the management and support of the Cyprus Agricultural Research Institute (Mavrogenis 2005; Mueller 2013).

Both programs started as centralized nuclei and evolved over time into a successful experience with a high participation of producers. Key ingredients for 
success were: (1) Long-term government and institutional support, triggered and kept in an increasing fashion due to the initiatives and negotiations by research and extension; (2) Effective participation of producers, along with continuous capacity building; (3) Pragmatic consideration of market opportunities, and in the case of Cyprus of the milk processing industry; and (4) Suitable dissemination schemes (Mavrogenis 2005; Mueller 2013).

\section{Crossbreeding}

Crossbreeding has been the most popular approach, often induced by governments, through the distribution of improved breeds to improve the low productivity of the base. The idea was influenced by the higher productivity of improved European breeds, assuming that these and their crossbreds will produce with no problem under the production conditions of the base (Iñiguez et al. 2013).

The plans were implemented without sufficient evaluation of the productivity of the target population, and adequate contemporary and comparative tests of production and adaptation, involving the exotic breeds, the target animals, and the crossbreds, in controlled and real production environments. Furthermore, prescriptions advocating crossbreeding were not accompanied by protocols that defined the degree of crossbreeding to be attained, or, as indicated earlier, the management conditions needed for the crossbred animals to produce (Bradford et al. 1987).

The results were not promising, particularly in areas exploited by extensive and semi-extensive production systems. In the semi-arid areas of Mexico and Venezuela, where these types of systems prevail, goat smallholders claim that although goat production was somehow improved, high grade goats as opposed to the local unimproved goats have difficulties to thrive in the local production environments. For instance, a permanent threat exists for high grade goats to damage their enlarged udders while they graze on thorny xerophytic vegetation, which translates to economic losses to the producer (Iñiguez et al. 2013).

In the region known as La Laguna in Mexico, a unique interaction between goat smallholder producers and the goat milk processing industry evolved through time, apparently induced only by the initiative of both the producers and the industry. Semi-extensive smallholder systems in this region produce milk that is sold to the industry for the processing of fudge and candy, products highly demanded in the country. Farmers use up to three European breeds, the Saanen, Alpine, and Anglo Nubian goats, acquired from the more specialized private sector. These breeds were crossed to local Criollo goats, without following an organized scheme. Criollo goats compared to the European breeds have low milk productivity, but they are well adapted to the semiarid environments where the animals graze and produce (Escareño 2010). Farmers claim that though some productivity improvement was achieved in their herds, this development was not sustainable. They mentioned that to keep up the achieved productivity levels, they continually need the exotic purebreds for crossing their animals, which infringes in their economy. Also, the management and raising conditions afforded by the producers appear to be unsuitable for the crossbreds. Farmers would be willing to find the means to stabilize production, blending the excellent milk production of the improved breeds with the adaptation of Criollo goats to the local conditions and management (ICARDA 2009).

In contrast to the smallholder systems, commercial livestock production was always able to adjust the production environments for crossbred and high grade animals, with satisfactory results, e.g. the intensive production of dairy goats in Mexico (Montaldo et al. 2010) and improved Merino sheep in Argentina (Mueller 2013).

Crossbreeding experiences underline the need for well designed crossbreeding studies, before the distribution of exotic animals and their crossbreds into a production environment. These should set up the most appropriate crossbreeding scheme, considering the participation of producers, the managerial conditions for the crossbred animals to produce, and the grading up level to be achieved.

\section{The development of the Indonesian Composite breed, example of well targeted approach}

The development of the Indonesian synthetic sheep, known as the Composite sheep, is an example of a careful analysis of the performance of local populations, the availability of feeding resources, potential candidates for crossbreeding, the correct evaluation of purebreds and crossbreds, and the setting of the level of crossbreeding and management of crossbred animals.

The Small Ruminant Collaborative Research Support Program in collaboration with the Indonesian Research Institute for Animal Production (IRIAP), set the fundamental steps of this crossbreeding plan. Firstly, the plan characterized the Sumatran and Javanese sheep in the 1980's, documenting their performance and adaptation (Iniguez et al. 1991; Inounu et al. 1993). At the same time, it also identified exuberant feed production under the Sumatran plantations that could well support sheep meat production, highly demanded in the country (Iniguez \& Sanchez 1990). This enhanced feed base could also 
support animals with higher growing rates than those of the small Sumatran (SS) sheep $(22 \mathrm{~kg})$. A crossbreeding strategy to improve the productivity of Sumatran sheep was then devised considering larger hair sheep breeds of tropical regions $(>35 \mathrm{~kg})$.

The program introduced and evaluated pure Saint Croix $(\mathrm{HH})$ sheep in comparative tests with the Sumatran $\times$ Saint Croix crosses (HS), all grazing on the vegetation under rubber plantations, the actual production environment. Based on well supported information on its excellent performance in humid tropical environments, the Barbados Blackbelly (BB) sheep was chosen as second candidate. The program introduced this breed using frozen semen due to the difficulty to introduce the purebred per se. Sumatran $x$ Saint Croix (HS), and Sumatran $\times$ Barbados Blackbelly (BS) F1 crosses were studied in contemporary comparisons with pure Sumatran (SS) ewes and Sumatran $x$ Fat Tail (ES) F1 crosses, showing the superiority of crossbred animals, as seen in Figure 1 (Gatenby et al. 1997; Doloksaribu et al. 2000; Handiwirawan et al. 2011). A synthetic $1 / 2$ Sumatran $\times$ $1 / 4$ Saint Croix $\times 1 / 4$ Barbados Blackbelly sheep was then produced benefiting from the adaptation and reproduction traits of the Sumatran sheep, and the adaptation, size and higher growth rates of Saint Croix and Barbados Blackbelly sheep (Setiadi \& Subandriyo 2007). The comparative analysis of this synthetic relative to the Sumatran breed showed its suitability and pertinence to produce under the conditions of tree plantations in Indonesia, as a technological alternative to benefit farmers from the enhanced demand for sheep meat in Indonesia (Subandriyo et al. 1996; Inounu 2011).

Unfortunately, the synthetic was not widely exploited in Sumatra due to the institutional decision to move it to Java. IRIAP's long-term commitment allowed the preservation of this synthetic that has the potential to serve anywhere in the tropical conditions provided enough feed is available. The dissemination of this synthetic breed has been conducted in several areas such as in Pandeglang, West Java (Isbandi 2013).

\section{A BETTER TARGETED APPROACH FOR THE TRANSFER OF BREEDING PLANS}

Various discussions of the shortcomings in transferring breeding strategies for smallholder systems, underlined the need for testing alternative approaches to this end (ICARDA 2005). On this basis the following aspects were considered by the working group for a better targeted approach:

1. Inclusion and participation of the community and producers, whatever the plan pursues (selection or crossbreeding), taking into account the community needs and expectations, as well as the environments and markets where the improved animals will produce.

2. Flexibility, allowing the adjustment of the complexity of the plan to the capacity of the community to execute the actions and discipline required during the implementation, to meet the proposed goals.

3. The long-term synergy between the community and a suitable supervising entity. No matter how simple the design the responsibility for the supervision should lie with institutions involving animal breeders, considering the fundamentals of quantitative genetics and genetic improvement.

The working group tried this approach in different regions, including Central Asia, Middle East, Ethiopia, and Latin America. The lessons learned thus far show that in spite of applying this better targeted approach, there remain important issues to consider to meet success.

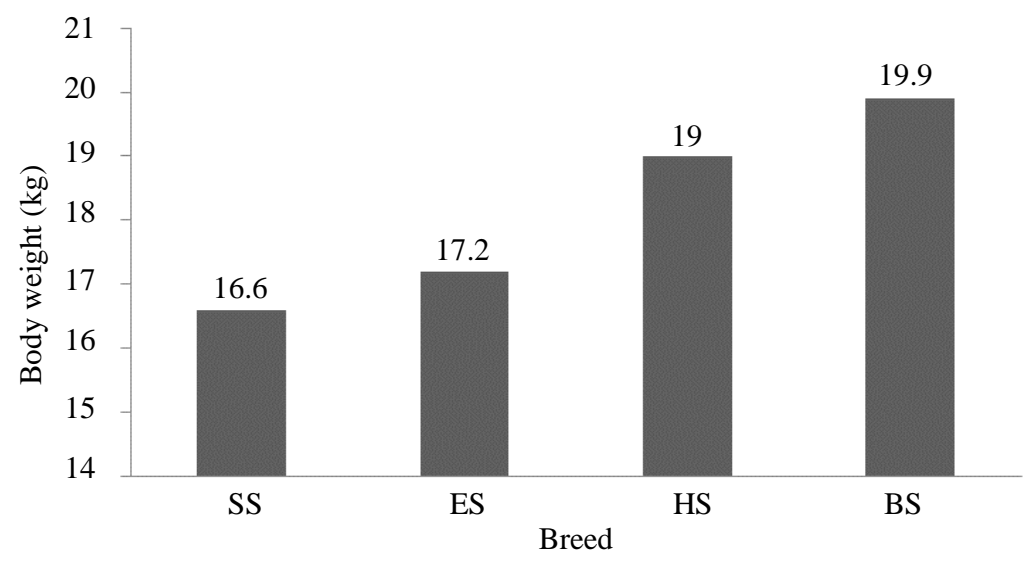

Figure 1.Lamb body weight of Sumatran pure (SS), Fat Tail Crosses (ES), St. Croix Crosses (HS), and Barbados Blackbelly Crosses (BS) at nine months of age, female only

Source: Gatenby et al. (1997) 


\section{LESSONS LEARNED IN THE IMPLEMENTATION OF THIS BETTER TARGETED APPROACH}

Iñiguez et al. (2013) and Wurzinger et al. (2011) identified the issues listed below as lessons learned in applying a better targeted approach are listed.

\section{Selection of the community and site}

In the selection of communities and sites, it is important to count on explicit expressions of interest to participate in a genetic improvement plan by the potential communities that could integrate the plan. Researchers, regional governments, and other organizations often select a site by criteria that do not translate the interests and aspirations of the communities residing in it. Selection decisions without the expressed consent of the communities should be avoided. Moreover, it is essential to assess the community's attitude to innovation. Conservative communities, reluctant to change, also should be avoided.

It is also crucial to count on information about the production systems available on the site, their constraints, and opportunities. Gaps of information could be rapidly filled in by the application of participatory methodologies. Subsistence systems with poor interaction with markets, with no chance to get access to productivity improvement plans (other than breeding) should be avoided.

The population stability trends on the site should also be assessed as people's migration has a negative impact on the implementation of a breeding plan. The political-administrative environment could be decisive during implementation and merits attention. Local governments, for instance, are equipped with organized institutions and trained personnel that could support the long-term projection of the plan if timely and strategically engaged.

\section{Expectations about the ownership of the plan and the plan's outcomes}

From design, it should be made clear that the community will own the breeding plan. That is a motivating measure to achieve a consistent adherence of its members to the proposed genetic improvement goals. Farmers should also be convinced of the longterm nature of a breeding plan and that this will deliver, as it is known, only small though cumulative gains per year.

\section{Documentation and information gaps}

Detailed process documentation is essential for impact and progress assessment, and for the dissemination of the strategy as a public good, should this become successful. Besides, poor documented information makes difficult to assess the reasons for successes and failures of breeding plans. Thus, efforts should be made to document apparently not relevant historical aspects, changes in direction during implementation, improvisations made to solve constraints, and descriptions of the potential and effective supporting environment and how it was engaged.

Linking the genetic and phenotypic characterization to the genetic improvement of the target base, notably benefits the plan. In particular capitalizes on adaptive features and special attributes of the base animals, otherwise ignored.

\section{The communication between supervising operators and the community}

There will be a need for strengthening the ability of the institutions for assessing the capacity and willingness of the community to carry out agreed actions and the discipline to be observed on a long-term basis. Although agricultural research institutions are now developing intense interactions with farmers, still show weaknesses in dealing with smallholders.

Gaining the trust of the community takes time and a desirable synchrony between the supervising entities and the communities. This justifies the identification of experienced staff to work as operators/coordinators to facilitate the required synchrony. To help in accelerating processes, this staff should be preferably hired on a full-time basis, with a base on the site. Such a measure provides more returns and benefits, in spite of the associated costs. The feedback to the producer, in particular about the information that is processed outside the production environment must be institutionalized in an improvement plan.

In defining breeding objectives, the variables that the producers consider important should not be ignored or eliminated. Because of the difficulty of handling many variables, say in a selection plan, supervising operators often opt for non consulted eliminations. It is preferable to invest in discussing with farmers to end with a manageable, coherent, and agreed list of variables than taking unilateral decisions in an environment that by definition is participatory. 


\section{Production records}

An almost insurmountable issue in the application of genetic improvement strategies in smallholder systems has been the fail to set up sustainable systems for animal production recording. Poor farmers do not keep records of production nor give priority to them.

This information in more economically developed countries is usually taken by specialized organizations at a cost subsidized by governments or producer associations. Where possible the responsibility should lie with these specialized entities (Facó et al. 2011). In case these institutions are unavailable or are reluctant to get involved, the support of regional or local governments, usually equipped with rural development personnel, could be explored and eventually engaged.

The producers should take part in the recording process, ensuring that they will facilitate the recording control, that recording dates are timely followed and occasionally verify recording quality. It is expectable for the producers to get simple production records, but it would be too optimistic to expect them to get involved in detailed and precise recording, simply because their work schedule would not let such an expectation. Production recording for meat and fiber is easy to carry out, but not for traits involving repeated measurements such as milk production. In these cases it will be important to identify variables easy to be measured, which are correlated with production traits. For example linear udder traits, correlated with milk production, plus a strictly necessary number of milk yield measurements (Casu et al. 2006; Iniguez et al. 2009).

In some circumstances, local knowledge could be an important entry point, e.g. Awassi sheep producers in the Middle East showed an outstanding ability to categorize productive and non-productive sheep, ability highly correlated to quantitative production evaluations (Iniguez et al. 2009). Research has an open field to explore simplifications to the recording process.

\section{Local knowledge}

In the absence of formal breeding plans, some communities developed innovative approaches that established a genetic structure, defining incipient genetic improvement practices (Mueller 2013). It is important to explore the communities' practices in this context and integrate them into a more structured improvement plan. The experience of working with smallholders shows that effective changes are achieved in less time in the production systems by building on prior knowledge.

\section{Production improvement (other than breeding)}

As the breeding plan advances due modifications in the production environment could be required, since $\mathrm{G} \times \mathrm{E}$ interactions are expected to change. More likely the improved genotypes will require specific conditions to express their potential that should be ensured. Therefore, it is of outmost importance to either linking to existing plans for the improvement of the feeding systems, forage or range production, and animal health, or inducing this improvement during implementation.

\section{On policies, development and sustainability}

The absence or non pertinence of specific policies targeting the development and improvement of smallholder systems generates a negative chain reaction to the establishment and success of genetic improvement plans. It diverts the attention and focus of the institutions with the potential to support the plan. The budgets available for these institutions are correspondingly affected, so that a long-term financial assistance, a sine qua non of a genetic improvement plan, is not viable. The chance for establishing an effective recording system is minimized and so does the ensuring of the access to non-genetic improvement efforts when the interactions $\mathrm{G} \times \mathrm{E}$ effects become evident. Finally, genetic improvement is excluded from development action and with this from the enabling environments offered by development programs. With no doubt without a government's political will translated into specific policies and development, a true and sustainable genetic improvement strategy for smallholders could not be possible.

In formulating community-based breeding plans, it is necessary reviewing existing policies and norms about the use of animal genetic resource and linking to these policies whether they exist. In negative cases or the case of weak policy development, there is a need for proactive action of institutions and communities towards including genetic improvement in government policies about the use of genetic resources by poor producers. Thus, development plans that carry out these policies could well accommodate and support longterm genetic improvement.

Most projects that start breeding plans have limited funding and short duration (2-3 years), conditions that are insufficient to consolidate actions and objectives. The implementation of a plan is a relatively easy task, but its sustainability is not a straightforward issue. Therefore, avoid initiating plans without first considering the key aspects of their 
sustainability. This implies realistic assessments from inception and permanent evaluations during the implementation period.

In this context and when possible, linking the plan to enabling environments can help to ensure sustainability. For example, with development projects that besides reflecting national priorities can offer the necessary infrastructure, logistics and funding, at least on a mid-term basis.

\section{CONCLUSION}

The transfer of small ruminant breeding strategies in smallholder systems is not a straightforward task. Contrasting a successful application in commercial livestock production environments, the achievement of the main objectives in smallholder systems requires a holistic approach beyond pure technical matters. Of all identified aspects with direct incidence in the implementation of breeding plans, the lack of specific national policies coupled with long-term funding to support the improvement of smallholder production systems, and the lack of involvement and participation of the communities emerge as issues that gravitate more to achieve sustainability and meet the objectives of a given breeding plan.

\section{REFERENCES}

Bradford GE, Subandriyo, Iniguez L. 1987. Breeding strategies for small ruminants in integrated croplivestock production systems. In: Small Ruminant Production Systems in South and Southeast Asia. Proceedings. Bogor, October 6-10, 1986. Ottawa (Canada): IDRC. p. 318-331.

Casu S, Pernazza I, Carta A. 2006. Feasibility of a linear scoring method of udder morphology for the selection scheme of Sardinian sheep. J Dairy Sci. 89:22002209.

Doloksaribu M, Gatenby RM, Subandriyo, Bradford GE. 2000. Comparison of Sumatra sheep and hair sheep crossbreds. III. Reproductive performance of F2 ewes and weights of lambs. Small Rumin Res. 38:115-121.

Escareño L. 2010. Design and Implementation of a community-based goat breeding program for smallholders in the North of Mexico [PhD Thesis]. [Vienna (Austria)]: University of Natural Resources and Applied Life Sciences.

Facó O, Lôbo RNB, Gouveia AMG, de Paiva Guimarães MPSLM, Fonseca JF, dos Santos TNM, da Silva MAA, Villela LCV. 2011. Breeding plan for commercial dairy goat production systems in southern Brazil. Small Rumin Res. 98:164-169.

Gatenby RM, Bradford GE, Doloksaribu M, Romjali E, Pitono AD, Sakul H. 1997. Comparison of Sumatra sheep and three hair sheep crossbreds. I. Growth, mortality and wool cover of F1 lambs. Small Rumin Res. 25:1-7.

Handiwirawan E, Noor RR, Sumantri C, Subandriyo. 2011. The differentiation of sheep breed based on the body measurements. J Indonesian Trop Anim Agric. 36:1-8.

ICARDA. 2005. Design and implementation of small ruminant breeding plans for small producers. regional planning workshop. Beirut (Lebanon): International Center for Agricultural Research in the Dry Areas.

ICARDA. 2009. Strengthening institutional capacity to improve marketing of small ruminant products and income generation in dry areas of Latin America. Final Project Report 2003-2008. Beirut (Lebanon): International Center for Agricultural Research in the Dry Areas.

Iniguez L. 2011. The challenges of research and development of small ruminant production in dry areas. Small Rumin Res. 98:12-20.

Iñiguez L. 2005a. Characterization of small ruminant breeds in West Asia and North Africa. Vol. II. Aleppo (Syria): International Center for Agricultural Research in the Dry Areas.

Iñiguez L. 2005b. Characterization of small ruminant breeds in West Asia and North Africa. Vol. I. Aleppo (Syria): International Center for Agricultural Research in the Dry Areas.

Iniguez L, Hilali M, Thomas DL, Jesry G. 2009. Udder measurements and milk production in two Awassi sheep genotypes and their crosses. J Dairy Sci. 92:4613-4620.

Iñiguez L, Mueller JP, Facó O, Wurzinger M, Sölkner J, Rodríguez T, Salinas-González H. 2013. Constraints and sustainability of community-based genetic improvement for smallholder systems in the dry areas of Latin America. In: Small ruminant production in the dry areas of Latin America. Embrapa (Brazil): International Center for Agricultural Research in the Dry Areas. p. 515-538.

Iniguez L, Sanchez M, Ginting S. 1991. Productivity of Sumatran sheep in a system integrated with rubber plantation. Small Rumin Res. 5:303-317.

Iniguez LC, Sanchez MD. 1990. Integrated tree cropping and small ruminant production systems. In: Proceedings of a Workshop on Research Methodologies. Medan, September 9-14, 1990. Bogor (Indonesia): ICARD and SR-CRSP.

Inounu I. 2011. The establishment of Composite sheep through cross-breeding technology in efforts to improve genetic quality of local sheep. Pengemb Inov Pertan. 4:218-230.

Inounu I, Iniguez L, Bradford GE, Subandriyo, Tiesnamurti B. 1993. Production performance of prolific Javanese ewes. Small Rumin Res. 12:243-257. 
Isbandi. 2013. Formation of integrated sheep village as effort to bring livestock technology to farms community. Wartazoa. 23:115-121.

Mavrogenis AP. 2005. Small ruminant breeds of Cyprus. In: Iñiguez L, editor. Characterization of small ruminant breeds in West Asia and North Africa. Vol. I. Aleppo (Syria): International Center for Agricultural Research in the Dry Areas. p. 417-458.

Montaldo HH, Torres-Hernández G, Valencia-Posadas M. 2010. Goat breeding research in Mexico. Small Rumin Res. 89:155-163.

Mueller JP. 2013. Experiences with genetic structures for the genetic improvement of small ruminants in the dry areas. In: Iñiguez L, editor. Small ruminant production in the dry areas of Latin America. Embrapa (Brazil): International Center for Agricultural Research in the Dry Areas. p. 497-513.

Setiadi B, Subandriyo. 2007. Productivity of Sumatera Composite dan Barbados Cross sheep breed in the field condition. JITV. 12:306-310.

Subandriyo, Setiadi B, Rangkuti M, Dwiyanto K, Batubara LP. 1996. Synthetic sheep from crosses between Sumatran and hair sheep breeds. Bogor (Indonesia): Puslitbangnak.

Wurzinger M, Sölkner J, Iñiguez L. 2011. Important aspects and limitations in considering community-based breeding programs for low-input smallholder livestock systems. Small Rumin Res. 98:170-175. 